Research Paper

\title{
Deguelin Attenuates Allergic Airway Inflammation via Inhibition of NF-kb Pathway in Mice
}

\author{
Zhang Bao ${ }^{1 *}$, Pei Zhang ${ }^{1 *}$, Yinan Yao ${ }^{1}$, Guohua Lu ${ }^{1}$, Zhongkai Tong ${ }^{2}$, Bing Yan ${ }^{1}$, Lingfang Tu${ }^{1}$, Guangdie \\ Yang ${ }^{1}$, Jianying Zhou ${ }^{凶}$ \\ 1. Department of Respiratory Diseases, The First Affiliated Hospital, School of Medicine, Zhejiang University, Hangzhou, China; \\ 2. Department of Respiratory Diseases, Ningbo No.2 hospital, Ningbo, China. \\ * These authors contributed equally to this work. \\ $\triangle$ Corresponding author: Prof. Jianying Zhou, Department of Respiratory Diseases, The First Affiliated Hospital, School of Medicine, Zhejiang University, 79 \\ Qingchun Road, Hangzhou 310003, Zhejiang Province, China. Tel/fax: +86 5718723 6876; E-mail: zjyhz@zju.edu.cn. \\ (c) Ivyspring International Publisher. This is an open access article distributed under the terms of the Creative Commons Attribution (CC BY-NC) license \\ (https://creativecommons.org/licenses/by-nc/4.0/). See http://ivyspring.com/terms for full terms and conditions.
}

Received: 2016.08.17; Accepted: 2017.03.02; Published: 2017.04.08

\begin{abstract}
Asthma is a chronic respiratory disease characterized by airway inflammation and remodeling, resulting in a substantial economic burden on both patients and society. Deguelin, a constituent of the Leguminosae family, exhibits anti-proliferative and anti-inflammatory activities in cancer mice models via inhibiting phosphatidylinositol 3-kinases and the NF-KB pathway. We demonstrated that deguelin effectively reduced OVA-induced inflammatory cell recruitment, decreased lung tissue inflammation and mucus production, suppressed airway hyperresponsiveness, and inhibited serum immunoglobulin and Th2 cytokine levels in a dose-dependent manner in asthmatic mice. In addition, we found that deguelin reduced inflammatory gene expressions both in vivo and in vitro, which were closely associated with activation of the NF-KB signaling pathway. Thus, we further explored the underlying mechanisms of deguelin in normal human bronchial epithelial cells (BEAS-2B). Our results suggested that deguelin inhibited NF-KB binding activity by enhancing the ability of IKBa to maintain NF-KB in an inactive form in the cytoplasm and preventing the TNF- $\alpha$ induced translocation of $p 65$ to the nucleus. In conclusion, our research indicates that deguelin attenuates allergic airway inflammation via inhibition of NF-KB pathway in mice model and may act as a potential therapeutic agent for patients with allergic airway inflammation.
\end{abstract}

Key words: Asthma; Deguelin; Inflammation; NF-кB pathway; TSLP.

\section{Introduction}

Asthma is one common chronic disease in the world that is characterized by chronic airway inflammation, mucus hypersecretion, and airway hyperresponsiveness (AHR), with a high incidence of about 334 million patients worldwide [1]. Early life exposures, environmental impacts including bacteria, toxins, viruses and air pollution, as well as childhood obesity are significant risk factors for the pathogenesis of asthma [2]. Accumulating evidence has shown that inflammatory responses of asthma are mediated by T-helper type 2 (Th2) cytokines including IL-4, IL-5, IL-9, and IL-13, which are critical for the synthesis of immunoglobulin IgE, the switch of T-helper cells toward the Th2 phenotype, and the survival of eosinophils [3]. It has been suggested that alterations in cytokines network, including the overproduction of Th2 cytokines (interleukin [IL]-4, IL-5, and IL-13), the reduction in Th1 cytokines (interferon [IFN]- $\gamma$ and IL-2), and abnormalities of IL-17, TGF- $\beta$, and thymic stromal lymphopoietin (TSLP), are involved in pathophysiology of asthma [4]. A variety of innate immune cells, such as dendritic cells, mast cells, and epithelial cells, also contribute to the airway inflammation of asthma. Furthermore, nuclear factors, such as nuclear factor-kB (NF-kB) and GATA-3, have been shown to regulate asthmatic related genes [5]. Although there are advances of understanding the mechanisms of asthma, effective therapies controlling 
the refractory asthmatic inflammation are still limited.

Deguelin is a member of the rotenoid family, isolated from several plant species, including derris trifoliate and Mundulea sericea, which are members of the Leguminosae family. Previously researches have shown that deguelin can suppress the proliferation, invasion and migration of various types of cancer cells through down-regulating the activation of phosphatidylinositol 3-kinases (PI3K)/Akt, mitogen-activated protein kinase (MAPK), fibroblast growth factor receptor-4 (FGFR4), and vascular endothelial cell growth factor-D [6-9]. In addition, deguelin has been shown to down-regulate tumor necrosis factor- $\alpha$ (TNF- $\alpha$ ) induced the NF-kB signaling pathway, which plays a critical role in the regulation of inflammation [10, 11]. Moreover, deguelin have been shown to exhibit anti-inflammatory activity through the suppression of lipopolysaccharide (LPS)-induced nitric oxide (NO)/inducible nitric oxide synthase (iNOS) expression [12]. Although deguelin has been explored effectively in the cancer therapy, it is unknown about anti-inflammatory effects of deguelin in asthma. Thus, potential effects and mechanisms of deguelin in inflammation are still need to be illustrated.

In the present study, we investigated anti-inflammatory effects and mechanisms of deguelin in a murine asthmatic model. We found that deguelin effectively reduced ovalbumin (OVA)-induced inflammatory cell recruitment, decreased lung tissue inflammation and mucus production, suppressed AHR, and inhibited serum immunoglobulin and Th2 cytokine levels and inflammatory gene expressions. In addition, we assessed the levels of NF-kB signaling molecules both in vivo and vitro with stimulation of deguelin, and found out that deguelin markedly inhibited phosphorylation of NF- $\mathrm{kB}$ p65 subunit and inhibitor of $\kappa \mathrm{Ba}(\mathrm{I} \kappa \mathrm{Ba})$, reduced degradation of $\mathrm{I} \kappa \mathrm{Ba}$ and nuclear translocation of $\mathrm{p} 65$. We demonstrated that deguelin attenuates allergic airway inflammation in a murine asthmatic model by inhibiting the activation of NF-kB pathway, and may be a potential therapeutic agent for asthma.

\section{Materials and Methods}

\section{Animals}

Male BALB/c mice, 4-6 weeks old (weight 20 to $22 \mathrm{~g}$ ) and free of specific pathogens, were purchased from Shanghai Slac Laboratory Animal Co. Ltd (Shanghai, China). Mice were housed for 3 days to adapt themselves to the environment before experiments. Mice were housed in micro-isolator cages and received food and water ad libitum. Experiments in this study were approved by the Animal Experiments Committee of Zhejiang University, and were performed in accordance with the Chinese National Regulations for Animal Care.

\section{Antigen Sensitization, Challenge and Treatment}

BALB/c mice were sensitized using an intraperitoneal (i.p.) injection of $25 \mu$ g OVA (Grade V, Sigma-Aldrich, St. Louis, MO, USA) in $0.1 \mathrm{~mL}$ alum on days 0 and 14 . On days 21, 22, and 23, mice were challenged by $2 \%$ OVA for $20 \mathrm{~min}$ in phosphate-buffered saline (PBS), using an ultrasonic nebulizer. Control mice were subjected to the same protocol, but received PBS instead of OVA in the challenge phase. Deguelin (purity $>98 \%$, power, Sigma-Aldrich, St. Louis, MO, USA) was prepared by dissolving in dimethyl sulfoxide (DMSO) with final concentration of DMSO to $0.1 \%(\mathrm{v} / \mathrm{v})$. Deguelin $(1 \mathrm{mg} / \mathrm{kg}, 4 \mathrm{mg} / \mathrm{kg})$ [10] in $0.1 \mathrm{ml}$ saline was given by intraperitoneal injection $1 \mathrm{~h}$ before each OVA aerosol challenge. Saline or dexamethasone (DXM, 1mg/kg) was used as a negative or positive control. The schematic diagram of the treatment schedule is presented in Figure 1.

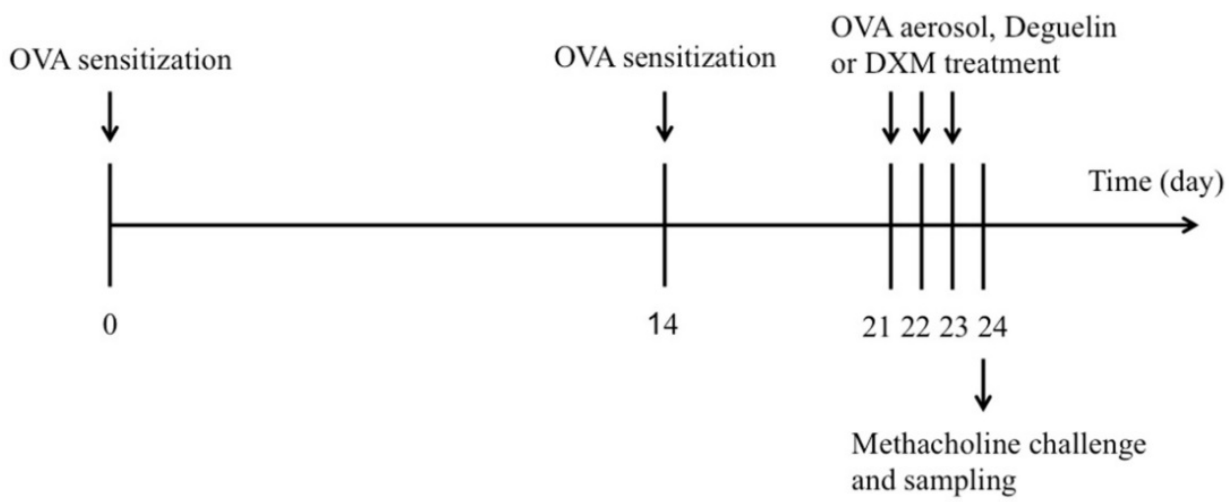

Figure 1. Experimental protocol for the development of allergic asthma and treatment with deguelin or dexamethasone (DXM). The mice were divided into five groups ( $n=12$ in each group) and sensitized to OVA on days 0 and 14 . Subsequently, mice were intraperitoneally injected with deguelin or DXM $1 \mathrm{~h}$ before challenged by $2 \%$ OVA for $20 \mathrm{~min}$ in PBS on days 21-23. Mice were sacrificed on day 24. 


\section{Bronchoalveolar Lavage Fluid (BALF) Collection}

Mice were anesthetized $24 \mathrm{~h}$ after the last aerosol challenge and BALF was performed as previously described [13]. Ice-cold PBS $(0.4 \mathrm{~mL})$ was instilled three times into the lungs, and BALF was collected. The fluid recovered from each sample was centrifuged $\left(4^{\circ} \mathrm{C}, 400 \mathrm{~g}, 5 \mathrm{~min}\right)$ to pellet the cells, and the supernatant was kept at $-80^{\circ} \mathrm{C}$ until it was used for cytokine measurements. Total cell counts were performed using an automated cell counter (Invitrogen, Waltham, MA, USA). The cell pellets were resuspended in PBS and differential cell counts were performed using the Wright's staining (BASO, Zhuhai, China) method. At least 200 cells were counted per slide by two researchers independently.

\section{Histologic Examination}

Lungs were fixed with $10 \%$ formalin, embedded in paraffin, sectioned into $5 \mu \mathrm{m}$ slices, and stained with Hematoxylin and Eosin (H\&E) (Sigma-Aldrich, St. Louis, MO, USA) for the detection of inflammatory cells and Periodic-Acid-Schiff (PAS) for analysis of mucus secretion in the goblet cells of the lung epithelium. The AB/PAS-stained epithelial areas of lung sections were captured using a light microscope (DP20, Olympus, Melville, NY, USA), and quantitative analysis was performed blinded as described before [14].

\section{Measurements of AHR}

AHR was assessed by whole-body plethysmography (Buxco Electronics, Troy, NY, USA) after the last OVA inhalation. Mice were placed in measured chambers. Aerosolized normal PBS or methacholine in increasing concentrations (3.125-50 $\mathrm{mg} / \mathrm{ml}$ ) were nebulized via chamber inlet for $90 \mathrm{~s}$. Recording and baseline were averaged for $3 \mathrm{~min}$ after each nebulization of variant methacholine concentration. AHR was expressed as enhanced pause (Penh), a calculated unit-less value that correlates the airway resistance, impedance, and intrapleural pressure within the same animal.

\section{Determination of serum immunoglobulin production}

Total serum IgE, IgG1 and IgG2a levels were measured using the ELISA kits (eBioscience, San Diego, CA, USA), according to the manufacturer's instruction. Briefly, blood was collected $24 \mathrm{~h}$ after the last challenge. Serum samples collected from eyes after sacrificing were stored at $-80^{\circ} \mathrm{C}$ until measurement. The plates were coated with purified anti-mouse IgE, IgG1 and IgG2a, washed and blocked, and diluted serum was then added.
Biotinylated anti-mouse immunoglobulins were used for detection of the antibody. Purified mouse immunoglobulins were used as the standards. After incubation with the substrate, the plates were read at $450 \mathrm{~nm}$ using an ELISA reader (Bio-Rad, CA, USA).

\section{Cell Cultures}

Normal human bronchial epithelial cells (BEAS-2B) were purchased from ATCC (CRL-9609, Rockville, MD, USA). BEAS-2B cells were plated into six-well plates at a concentration of $1 \times 10^{6} \mathrm{cells} /$ well and cultured in DMEM/F12 (Gibco, ThermoFisher Scientific, Waltham, MA, USA) containing $10 \%$ fetal bovine serum (FBS, Clark Bioscience, Houston, Texas, USA), supplemental with 100units/ml penicillin and $100 \mathrm{ug} / \mathrm{ml}$ streptomycin (Sigma-Aldrich, St. Louis, $\mathrm{MO}, \mathrm{USA})$. Cells were cultured at $37^{\circ} \mathrm{C}$ in $5 \% \mathrm{CO}_{2}$ in a humidified incubator.

\section{Cell Viability Assay}

The BEAS-2B cells were plated in 96-well plates at a density of $5 \times 10^{3}$ cells/well and treated with different concentrations of deguelin [10, 15]. After incubation for $24 \mathrm{~h}$, cell viability was measured in triplicate using a Cell Counting Kit-8 (Dojindo Laboratories, Tokyo, Japan) according to the manufacturer's protocol. The absorbance value was measured at $450 \mathrm{~nm}$ using a Microplate Reader (Bio-Rad, CA, USA) and the measured absorbance was converted to the percentage $(\%)$ of the control value.

\section{Cytokines ELISA Analysis}

The concentrations of cytokines (IL-4, IL-5, IL-13 and IFN- $\gamma$ ) in the BALF supernatant were measured by sandwich ELISA kits (eBioscience, San Diego, CA, USA) specific for mice, following the manufacturer's instructions. The ELISA kits show no cross-reactivity with any of the cytokines tested at $50 \mathrm{ng} / \mathrm{mL}$. The plates were read at $450 \mathrm{~nm}$ using an ELISA reader (Bio-Rad, CA, USA).

\section{RNA Preparation and Real-time PCR analysis}

Total RNA from lung tissues and cells were extracted using TRIzol reagent (Takara Bio, Shiga, Japan), and finally diluted in nuclease-free DEPC-treated water. RNA quantity and purity were calculated using the absorbance at $260 / 280 \mathrm{~nm}$ value using a Nanodrop (Thermo Fisher Scientific, Waltham, MA, USA). For real-time reverse transcriptase polymerase chain reaction (RT-PCT) analysis, the following components were added to a $10 \mu$ l reaction volume: $1 \mu \mathrm{l}$ of cDNA, $0.4 \mu \mathrm{l}$ of each forward and reverse primer $(10 \mu \mathrm{M}$ initial concentration), $0.2 \mu$ l of $50 \times$ ROX Reference Dye II, $3 \mu 1$ of PCR grade water, and $5 \mu$ l of $2 \times$ SYBR Premix Ex 
TaqTM II (Takara Bio, Japan). The sequences of the primer pairs are listed in Table 1. PCR conditions consisted of one $30 \mathrm{~s}$ cycle at $95^{\circ} \mathrm{C}$, followed by 40 cycles of $95^{\circ} \mathrm{C}$ for $5 \mathrm{~s}$ and $60^{\circ} \mathrm{C}$ for $34 \mathrm{~s}$, followed by a melting curve analysis. PCR reactions and analysis were performed using a 7500 Real Time PCR system (Applied Biosystems; Life Technologies, Grand Island, NY, USA). The expression of target genes was calculated by the $2^{-\Delta \Delta \mathrm{CT}}$ method, and normalized to $\beta$-actin values.

\section{Western Blot Analysis}

Lung samples were grounded into powder in liquid nitrogen, and lysed in ice-cold lysis buffer $(2 \%$ Triton X-100, $10 \mathrm{mM}$ Tris-HCl, $\mathrm{pH}$ 8, $150 \mathrm{mM} \mathrm{NaCl}, 2$ $\mathrm{mM}$ NaN3, $2 \mathrm{mM}$ EDTA) containing protease inhibitors for $2 \mathrm{~h}$ at $4^{\circ} \mathrm{C}$. Cells were washed in PBS and lysed in ice-cold lysis buffer containing protease inhibitors for $1 \mathrm{~h}$ at $4^{\circ} \mathrm{C}$. Lysates were harvested and centrifuged at $12000 \mathrm{rpm}$ in a tabletop centrifuge to collect supernatant and were stored at $-20^{\circ} \mathrm{C}$ until further use. The nuclear protein was extracted according to the manufacturer's protocol of NE-PER Nuclear and Cytoplasmic Extraction Reagents (Thermo Fisher Scientific, MA, USA). Protein concentration was determined using the protein assay kit (Thermo Fisher Scientific, MA, USA). Cell lysates and supernatants were electrophoresed in a $10 \%$ or $12 \%$ sodium dodecyl sulfate polyacrylamide gel under non-reducing conditions and were transferred to nitrocellulose. Western blotting was performed using antibodies against NF-кB p65 (Ser ${ }^{536}$ ), ІкBa $\left(\mathrm{Ser}^{32}\right)$ as well as phosphor-specific antibodies for
NF-кB p65, ІкBa (Cell Signaling Technologies, Beverly, MA, USA), and an appropriate HRP-conjugated secondary antibody (ZSGB-BIO, Beijing, China). Equal loading of the lanes was confirmed by analyzing the blots for $\beta$-actin and Lamin B expression using an anti- $\beta$-actin and anti-Lamin B antibody (Boster Biological Technology, Wuhan, China). Bands were detected using an enhanced chemiluminescence reagent. Grey values were measured with Quantity One software (Bio-Rad, CA, USA).

\section{Flow Cytometry}

Cells purified from mouse lungs were resuspended and stained with FITC-conjugated anti-CD4 (BioLegend, San Diego, CA, USA), APC-conjugated anti-TSLP Receptor (R\&D Systems, Minnesota, USA), and the respective isotype control stains, according to the manufacturer's instructions (BD Pharmingen, San Diego, CA, USA). The fluorescent antibodies were added $(1 \mu \mathrm{g} / 100 \mu \mathrm{L})$ and incubated for $30 \mathrm{~min}$ at $4{ }^{\circ} \mathrm{C}$. Flow cytometry acquisition was performed using a FACS-Calibur (BD Bioscience, San Jose, CA, USA), and the results were analyzed using CellQuest software (BD Bioscience, San Jose, CA, USA).

\section{Statistical Analysis}

All data were presented as mean \pm SEM. Statistical differences were determined by Student's t-test and one-way ANOVA with SPSS 19.0 (SPSS, Chicago, IL, USA). Values with $P<0.05$ were considered statistically significant.

Table 1. primer sets for real-time reverse transcriptase polymerase chain reaction analysis

\begin{tabular}{lll}
\hline & Primer sequences & \\
\cline { 2 - 3 } Targets & Forward & Reverse \\
\hline IL-4 (mouse) & $5^{\prime}$-GAAAGAGACCTTGACACAGCTG & $5^{\prime}$-GAACTCTTGCAGGTAATCCAGG \\
IL-5 (mouse) & $5^{\prime}$-CACCAGCTATGCATTGGAGA & $5^{\prime}$-TTTGGCGGTCAATGTATTTCT \\
IL-13 (mouse) & $5^{\prime}$-TGTTCGCCACGGCCCCTTC & $5^{\prime}$-GCAGTGCAGGCTGAGGCCAA \\
IFN-y (mouse) & $5^{\prime}$-GCTACACACTGCATCTTGGCTTTG & $5^{\prime}$-CACTCGGATGAGCTCATTGAATGC \\
TSLP (mouse) & $5^{\prime}$-TTCACTCCCCGACAAAACATTT & $5^{\prime}$-TGGAGATTGCATGAAGGAATACC \\
E-selectin (mouse) & $5^{\prime}$-AACGCCAGAACAACAATTCC & $5^{\prime}$-TGAATTGCCACCAGATGTGT \\
Muc5ac (mouse) & $5^{\prime}$-GAGTGACATTGCAGGAAGCA & $5^{\prime}$-CAGAGGACAGGAAGGTGAGC \\
iNOS (mouse) & $5^{\prime}$-GTCAACTGCAAGAGAACGGAGAC & $5^{\prime}$-GAGCTCCTCCAGACGGGTAGGCTTG \\
E-selectin (human) & $5^{\prime}$-TCAAGTGTGAGCAAATTGTGAAC & $5^{\prime}$-ATTCTCCAGAGGACATACACTGC \\
Muc5ac (human) & $5^{\prime}$-CAGCACAACCCCTGTTCAAA & $5^{\prime}$-GCGCACAGAGGATGACAGT \\
TSLP (human) & $5^{\prime}$-ATGTTCGCCATGAAAACTAAGGC & $5^{\prime}$-GCGACGCCACAATCCTTGTA \\
RANTES (human) & $5^{\prime}$-CCAGCAGTCGTCTTTGTCAC & $5^{\prime}$-CTCTGGGTTGGCACACACTT \\
$\beta-A c t i n$ (both) & $5^{\prime}$-TCATGAAGTGTGACGTTGACATCCG & $5^{\prime}$-CCTAGAAGCATTTGCGGTGCACGATG \\
\hline
\end{tabular}




\section{Results}

\section{Deguelin suppressed OVA-induced inflammatory cell infiltration in asthmatic mice}

To examine the possible anti-inflammatory effect of deguelin on allergic airway reactivity, we treated asthmatic mice with different doses of deguelin intraperitoneally, for three consecutive days before OVA aerosol challenge. BALF was collected $24 \mathrm{~h}$ after the last OVA aerosol challenge, and then total and differential cell counts were performed. OVA-inhalation significantly increased total cell, eosinophil, macrophage, lymphocyte, and neutrophil counts in asthmatic mice compared to the saline challenged mice (Fig. 2). Both low and high doses of deguelin $(1 \mathrm{mg} / \mathrm{kg}, 4 \mathrm{mg} / \mathrm{kg})$ reduced total cell, eosinophil and lymphocyte counts compared to the OVA-challenged group (Fig. 2). Furthermore, the high dose of deguelin $(4 \mathrm{mg} / \mathrm{kg})$ markedly reduced total cell, eosinophil and macrophage counts as compared with the low dose of deguelin $(1 \mathrm{mg} / \mathrm{kg}$ ) (Fig. 2). Thus, these results suggested that deguelin reduced inflammatory cell recruitment in asthmatic mice in a dose-dependent manner.

Lung tissues were collected $24 \mathrm{~h}$ after the last aerosol challenge. Further histological examination of H\&E stained lung tissues revealed infiltration of inflammatory cells, especially lymphocytes and eosinophils after the OVA aerosol challenge (Fig. 3A and 3B). Treatment with deguelin $(4 \mathrm{mg} / \mathrm{kg})$ markedly reduced the degree of inflammatory cell infiltration in both peribronchial and perivascular connective tissues as compared with OVA-challenged group (Fig. $3 \mathrm{~A}$ and $3 \mathrm{~B})$. In addition, OVA-challenged mice showed a strong $\mathrm{AB} / \mathrm{PAS}$-positive staining in bronchial epithelial tissue, which indicated goblet cell hyperplasia and mucus production (Fig. 3C and 3D). Deguelin $(4 \mathrm{mg} / \mathrm{kg})$ treatment dramatically reduced goblet cell hyperplasia and mucus secretion as indicated in PAS staining (Fig. 3C, 3D and 3E). A high dose of deguelin $(4 \mathrm{mg} / \mathrm{kg})$ showed a lower percentage of $\mathrm{AB} / \mathrm{PAS}$-positive staining area compared with the low dose of deguelin $(1 \mathrm{mg} / \mathrm{kg})$ (Fig. 3E). These results indicated that deguelin inhibited OVA-induced lung tissue inflammation and mucus production.

\section{Deguelin reduced OVA-induced AHR in mice}

To investigate the effect of deguelin on AHR in response to increasing concentrations of methacholine, we measured Penh in response to nebulized methacholine $(3.125-50 \mathrm{mg} / \mathrm{ml})$ by whole-body plethysmography. Penh is a calculated unit-less value that correlates the airway resistance, impedance, and intrapleural pressure within the same animal $($ Penh $=$ pause $\times$ peak expiratory box flow/peak inspiratory bow flow). OVA-challenged mice remarkably up-regulated AHR compared to the PBS-challenged mice starting from $6.25 \mathrm{mg} / \mathrm{ml}$ of methacholine (Fig. 4). In addition, Penh was significantly reduced in deguelin $(4 \mathrm{mg} / \mathrm{kg})$-treated mice as compared with the OVA-challenged group starting from $12.5 \mathrm{mg} / \mathrm{ml}$ of methacholine (Fig. 4). The DXM-treated group, used as a positive control, also exhibited significantly reduced Penh values (Fig. 4). These results indicated that deguelin suppressed AHR in asthmatic mice and modified immune-mediated airway pathology in vivo.

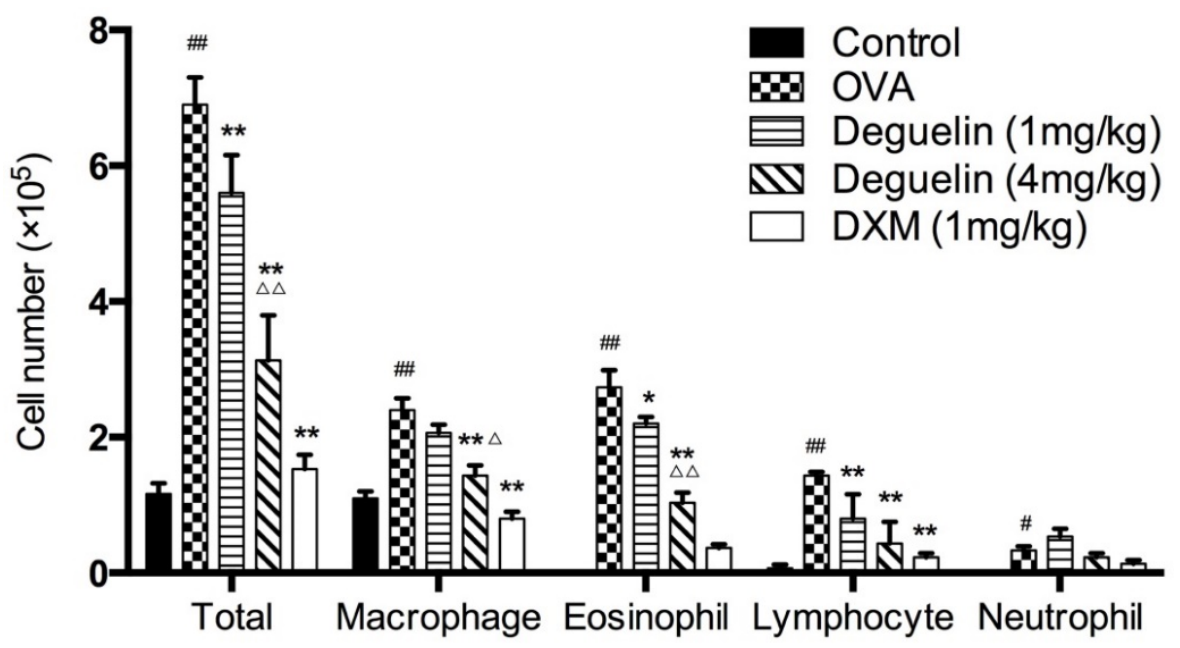

Figure 2. Deguelin suppressed OVA-induced inflammatory cell recruitment in a dose-dependent manner. Inflammatory cell counts in BALF were obtained from sensitized mice $24 \mathrm{~h}$ after the last aerosol challenge. The BALF was centrifuged, and the cell pellets were resuspended and applied to a slide to obtain differential cell counts by Wright staining. Values are shown as mean $\pm \operatorname{SEM}\left(n=6\right.$ for each group). $D X M=$ dexamethasone. ${ }^{\# P<0.05},{ }^{\# P} P<0.01$ vs. Control group; ${ }^{*} P<0.05,{ }^{* *} P<0.01$ vs. OVA-challenged group; $\triangle P<0.05, \triangle \triangle P<0.01 \mathrm{vs.} \mathrm{Deguelin}(1 \mathrm{mg} / \mathrm{kg})$ group. 


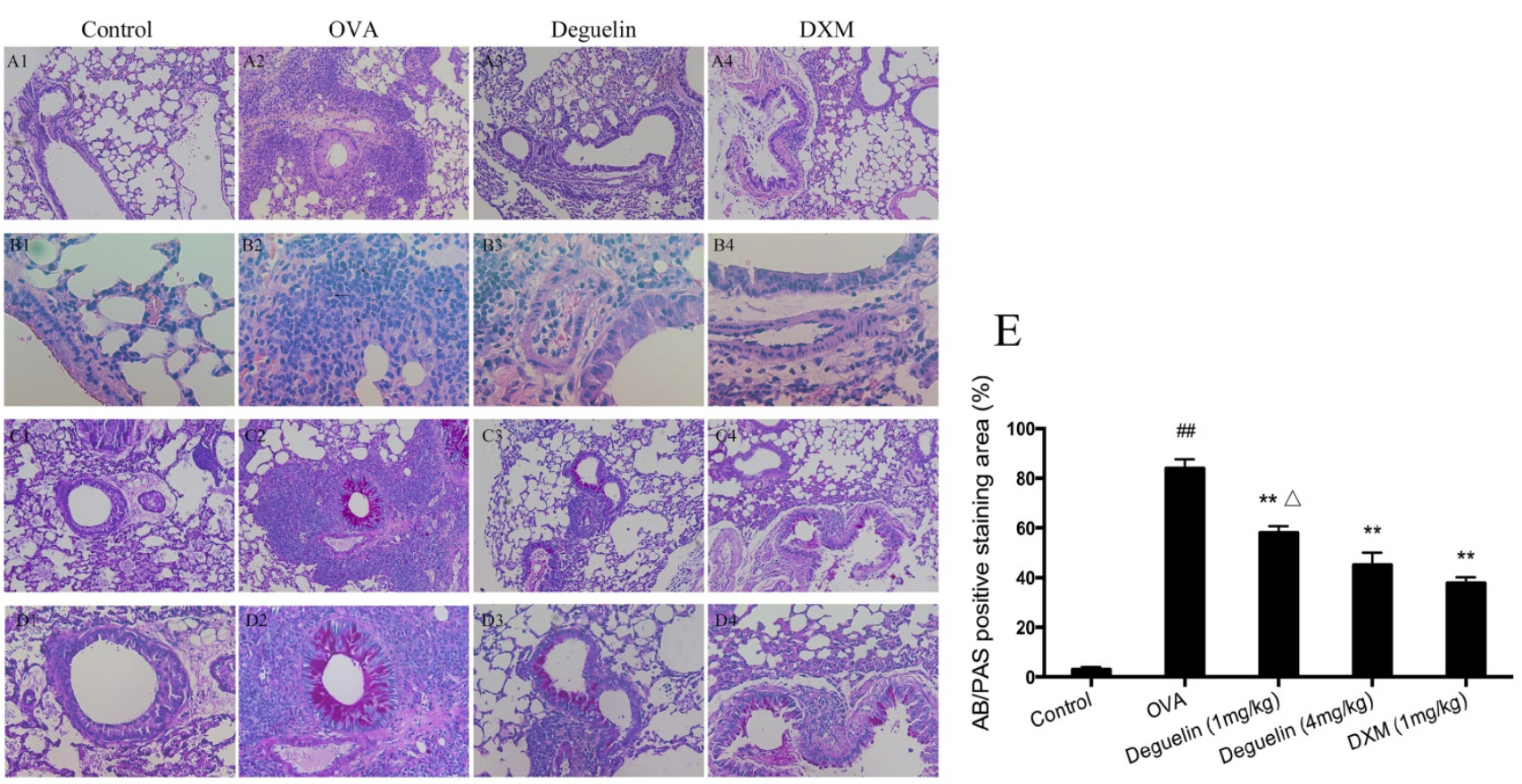

Figure 3. Deguelin inhibited OVA-induced airway inflammation and mucus production. (A, B) $24 \mathrm{~h}$ after the final challenge, lung tissues were obtained from controlled mice, OVA-sensitized and challenged mice, deguelin $(4 \mathrm{mg} / \mathrm{kg}, 1 \mathrm{mg} / \mathrm{kg})$ and dexamethasone $(1 \mathrm{mg} / \mathrm{kg})$ treated mice. Representative photomicrographs of hematoxylin-eosin (H\&E) stained lung sections from each group. (C, D) Alcian blue/periodic acid-schiff (AB/PAS) stained lung sections from each group. (E) The percentage of positively stained epithelial areas (AB/PAS). Arrowed in B2 showed eosinophil. A1-4, magnification $\times 100 ; \mathrm{B} 1-4$, magnification $\times 400$; $\mathrm{C1}-4$, magnification $\times 100$; D 1-4, magnification $\times 200$. Data are presented as the mean \pm SEM ( $n=6$ for each group). $\# P<0.05$, \#P<0.01 vs. Control group; ${ }^{*} P<0.05$, ${ }^{* *} P<0.01$ vs. OVA-challenged group; $\triangle P<0.05, \Delta \Delta P<0.01$ vs. Deguelin $(4 \mathrm{mg} / \mathrm{kg})$ group.

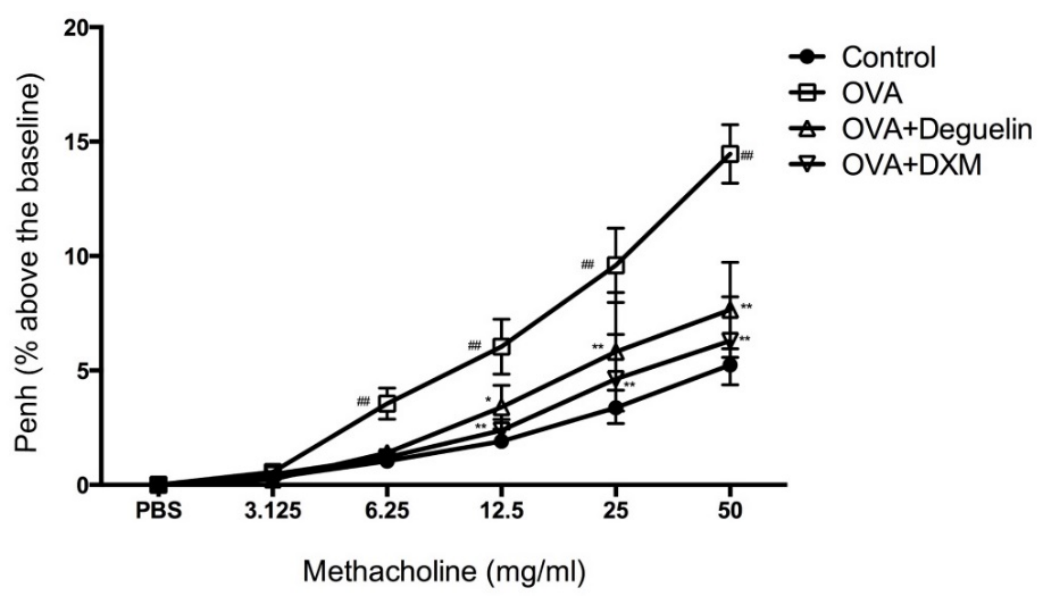

Figure 4. Effects of deguelin on AHR to methacholine in OVA-induced mice. Airway responsiveness of mice in response to aerosolized methacholine was measured $24 \mathrm{~h}$ after the last challenge with pretreatment of either deguelin $(4 \mathrm{mg} / \mathrm{kg})$ or dexamethasone $(1 \mathrm{mg} / \mathrm{kg})$. AHR was assessed and shown as Penh values. The results were expressed as percentage change in Penh above baseline. Values are shown as mean $\pm S E M(n=12$ for each group). $D X M=$ dexamethasone. $\# P<0.05$, \#P<0.01 vs. Control group; ${ }^{*} P<0.05,{ }^{*} P<0.01$ vs. OVA-challenged group.

\section{Deguelin reduced OVA-induced serum immunoglobulin production}

To further evaluate whether deguelin could modify an ongoing OVA-specific Th2 response in vivo, serum levels of total IgE, IgG1, and IgG2a were determined using ELISA. Marked elevation in serum total IgE and IgG1 were observed in OVA-challenged mice as compared with control group (Fig. 5A and 5B). Deguelin at both high and low doses $(4 \mathrm{mg} / \mathrm{ml}$ and $1 \mathrm{mg} / \mathrm{ml}$ ) strongly suppressed IgE and IgG1 levels compared with OVA-challenged group (Fig. 5A and $5 \mathrm{~B})$. The high dose of deguelin $(4 \mathrm{mg} / \mathrm{kg})$ showed a greater suppressive effect than the low dose $(1 \mathrm{mg} / \mathrm{kg})$ (Fig. 5A and 5B). There was no statistical difference in the level of serum IgG2a (Fig. 5C). Deguelin had effects on the serum levels of IgE and $\operatorname{IgG1}$, not IgG2a, indicating that a specific inhibition of the Th2 response by deguelin in murine asthmatic model. 


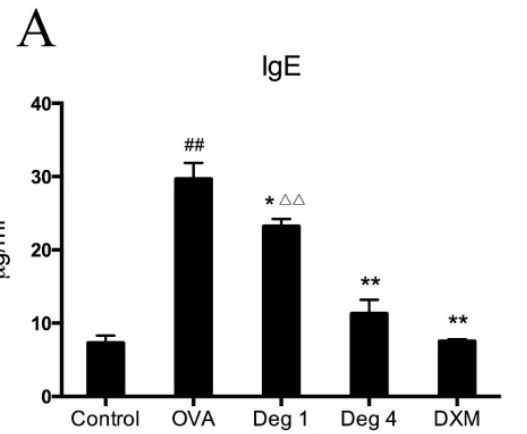

$\mathrm{B}$

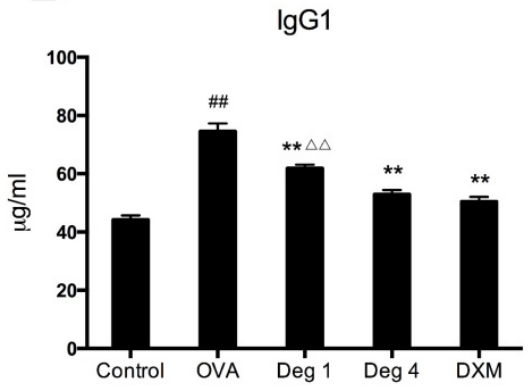

$\mathrm{C}$

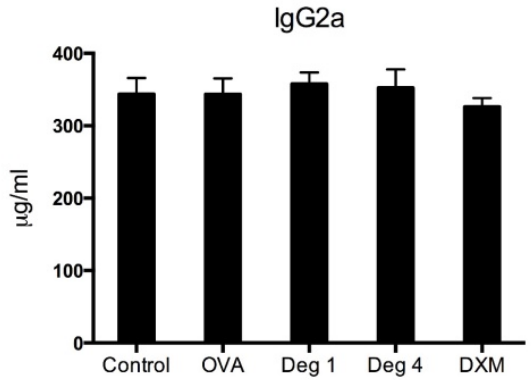

Figure 5. Effects of deguelin treatment on systemic immunoglobulin production in the serum of OVA-sensitized asthmatic mice. Serum was collected $24 \mathrm{~h}$ after the last OVA aerosol challenge. The levels of total lgE, IgG1 and IgG2a were analyzed using ELISA. Values are shown as mean \pm SEM ( $\mathrm{n}=6$ for each group). Deg $1=$ Deguelin 1mg/kg; Deg 4 = Deguelin $4 \mathrm{mg} / \mathrm{kg} ; \mathrm{DXM}=$ dexamethasone. $\# P<0.05, \# P<0.01$ vs. Control group; ${ }^{*} P<0.05,{ }^{* *} P<0.01$ vs. OVA-challenged group; $\triangle P<0.05$, $\triangle \Delta P<0.01$ vs. Deguelin $(4 \mathrm{mg} / \mathrm{kg})$ group.<smiles>[B]C</smiles>
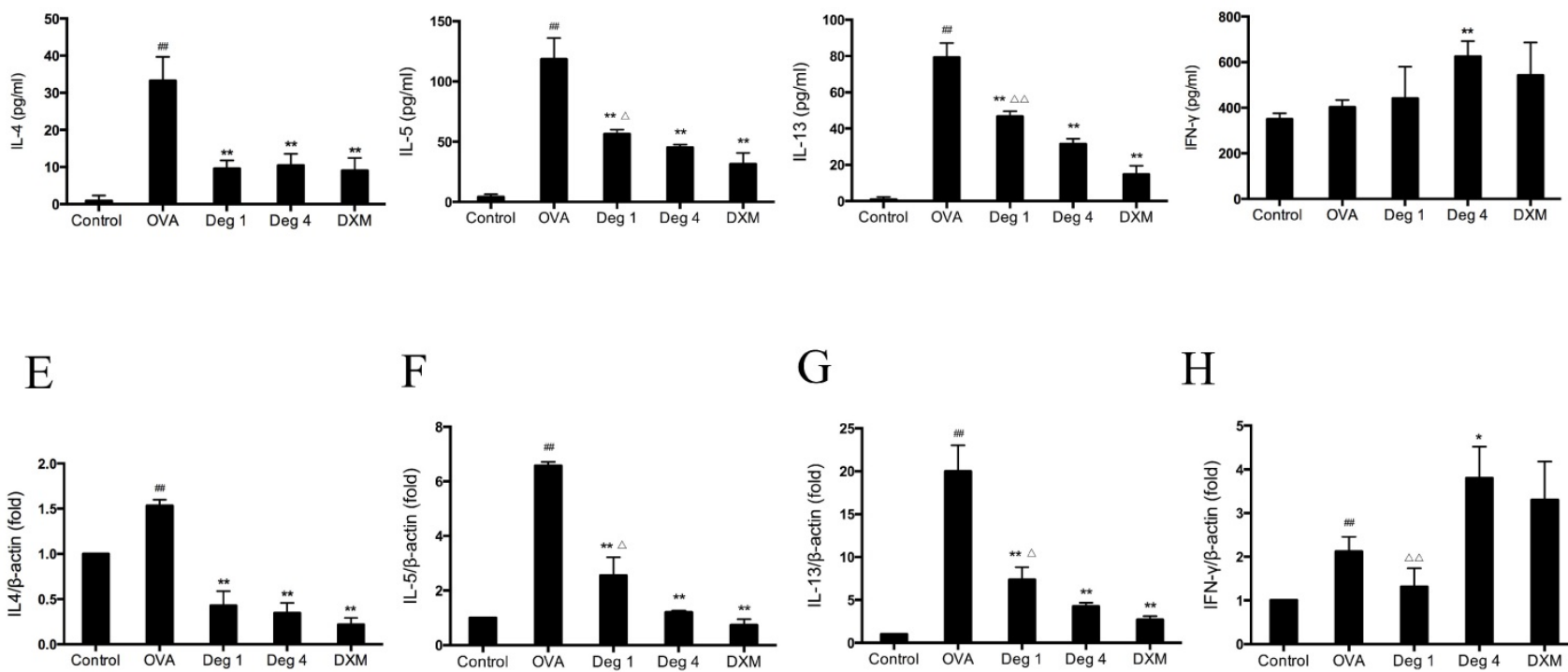

G

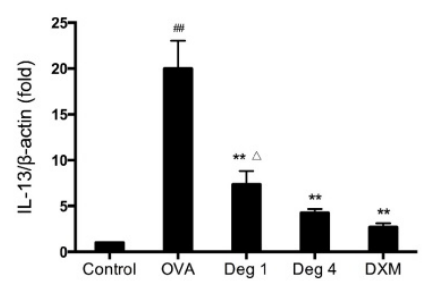

$\mathrm{H}$

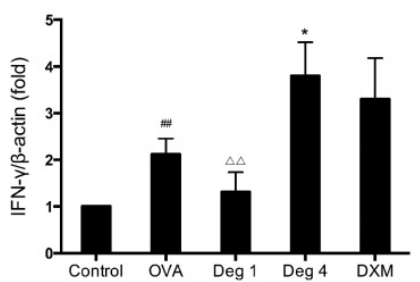

Figure 6. Deguelin reduced OVA-induced Th2 cytokine expression in lung tissues. (A, B, C, D) The BALF was collected $24 \mathrm{~h}$ after the last OVA aerosol challenge and centrifuged. The supernatants were collected. The levels of IL-4, IL-5, IL-13, and IFN- $\gamma$ were measured by ELISA. (E, F, G, H) Lung tissues were collected $24 \mathrm{~h}$ after the last OVA challenge. Total mRNA was extracted using TRIzol reagent. The gene expression of IL-4, IL-5, IL-13 and IFN-Y were detected by real-time RT-PCR. $\beta$-actin was used as an internal control. Values are shown as mean \pm SEM ( $=6$ for each group). Deg $1=$ Deguelin $1 \mathrm{mg} / \mathrm{kg} ; \mathrm{Deg} 4=\mathrm{Deguelin} 4 \mathrm{mg} / \mathrm{kg} ; \mathrm{DXM}=$ dexamethasone. ${ }^{*} P<0.05,{ }^{\# P}<0.01$ vs. Control group; ${ }^{*} P<0.05,{ }^{* *} P<0.01$ vs. OVA-challenged group; $\triangle P<0.05, \Delta \Delta P<0.01$ vs. Deguelin (4mg/kg) group.

\section{Deguelin reduced OVA-induced Th 2 cytokine expression}

To investigate whether deguelin could modify an OVA-specific Th2 response, Th2 cytokine levels in the BALF were measured by sandwich ELISA. OVA inhalation in sensitized mice caused a notable increase in IL-4, IL-5 and IL-13, as compared with control group (Fig. 6A, 6B and 6C). In contrast, there was no statistical difference in the level of IFN- $\gamma$, a Th1 cytokine (Fig. 6D, P>0.05). Deguelin $(4 \mathrm{mg} / \mathrm{kg}$, $1 \mathrm{mg} / \mathrm{kg}$ ) decreased levels of Th2-associated cytokines including IL-4, IL-5, and IL-13, in OVA-immunized mice (Fig. 6A, 6B and 6C). In addition, Deguelin at $4 \mathrm{mg} / \mathrm{kg}$ markedly increased IFN- $\gamma$ level in BALF compared with OVA-challenged group (Fig. 6D). Meanwhile, we collected lung tissues to evaluate gene expressions of Th2 cytokines. The real-time RT-PCR analysis revealed a significant decrease in the expression of Th2 cytokines, including IL-4, IL-5, and IL-13 in deguelin $(4 \mathrm{mg} / \mathrm{kg}, 1 \mathrm{mg} / \mathrm{kg})$ group compared with OVA-immunized group (Fig. 6E, 6F and 6G). Deguelin at $4 \mathrm{mg} / \mathrm{kg}$ increased the expression of IFN-Y (Fig. 6H). Moreover, the reduction of cytokine IL-5 and IL-13 was in a dose-dependent manner in asthmatic mice (Fig. 6B, 6C, 6F and 6G). These results implied that deguelin suppressed the Th2-predominant immune activity in OVA-induced murine asthmatic model. 


\section{Effects of deguelin on OVA-induced inflammatory gene expression in vivo}

To further evaluate effects of deguelin on inflammatory gene expression in asthmatic mice, we measured the expression of inflammation-associated gene in lung tissues by real-time RT-PCR. The mRNA levels of E-selectin, Muc5ac, iNOS and thymic stromal lymphopoietin (TSLP), which are essential for allergic airway inflammation and mucus secretion, markedly increased in OVA-challenged mice as compared with PBS-challenged control (Fig. 7A, 7B, 7C and 7D). Deguelin $(4 \mathrm{mg} / \mathrm{kg}$ and $1 \mathrm{mg} / \mathrm{kg})$ significantly suppressed expressions of E-selectin, Muc5ac, iNOS, and TSLP in the allergic airways (Fig. 7A, 7B, 7C and 7D). The high dose of deguelin $(4 \mathrm{mg} / \mathrm{kg})$ showed a greater suppressive effect than the low dose $(1 \mathrm{mg} / \mathrm{kg})$ (Fig. 7B, 7C and 7D).

Since TSLP plays a pivotal role in T-cell maturation and Th2 induction in asthma [16], we further investigated expression of TSLP on $\mathrm{CD} 4^{+} \mathrm{T}$ cells by flow cytometry. Fresh lung tissues were collected $24 \mathrm{~h}$ after the last aerosol challenge. Cells purified from lungs were resuspended and stained with FITC-conjugated anti-CD4 and APC-conjugated anti-TSLP Receptor. OVA challenge significantly increased TSLP expression on CD4 ${ }^{+} \mathrm{T}$ cells compared to PBS group (Fig. 7E and 7F). Deguelin dramatically decreased the level of TSLP expression in a dose-dependent manner (Fig. 7E and 7F). Taken together, deguelin dramatically reduced OVA-induced inflammatory gene expression in asthmatic model.

\section{Deguelin reduced TNF- $\alpha$ induced inflammatory gene expression in vitro}

Among the numerous intracellular signaling networks involved in the differentiation of $\mathrm{T}$ cells, the NF-KB pathway has emerged as an important contributor to this developmental process [17]. As mentioned earlier, deguelin has been reported to down-regulate TNF- $\alpha$ induced NF- $\mathrm{kB}$ activation in different kinds of cells. To further explore the anti-inflammatory mechanisms of deguelin in airways, we performed experiments on TNF-a induced inflammatory gene expression in normal human bronchial epithelial cells (BEAS-2B). Since cytokines of the TNF family trigger a variety of NF-kB-dependent responses that can be specific to both cell type and signaling pathway [18], and the mechanism of NF-KB activation is relatively well established, we investigated the effect of deguelin on TNF- $\alpha$ induced NF-KB activation in BEAS-2B cells. Before addressing the effect of deguelin on the TNF- $\alpha$ induced inflammatory gene expression in BEAS-2B cells, we measured cell viability after deguelin treatment for $24 \mathrm{~h}$. As a result, deguelin showed no cytotoxicity at concentrations less than $10 \mu \mathrm{M}$ (Fig. $8 \mathrm{~A})$. Subsequently, BEAS-2B cells were pre-incubated with deguelin $(10 \mu \mathrm{M})$ for $24 \mathrm{~h}$, and then stimulated with TNF-a $(10 \mathrm{ng} / \mathrm{ml})$ for $30 \mathrm{~min}$. DMSO was used as a negative control. The mRNA expression of E-selectin, Muc5ac, TSLP, and RANTES were evaluated by real-time RT-PCR. Deguelin noticeably blocked TNF-a-induced expression of E-selectin, Muc5ac, TSLP, and RANTES in BEAS-2B cells compared with control group (Fig. 8B, 8C, 8D and 8E). These results indicated that deguelin reduced NF-kB-associated inflammatory gene expression in BEAS-2B cells as similar with lung tissues which was described before.

\section{Inhibitory effects of deguelin on NF-KB activation in asthmatic model and BEAS-2B cells}

To further explore mechanisms of deguelin, we first investigated effects of deguelin on NF- $\mathrm{KB}$ activation in mice with OVA-challenged asthma. Total protein, cytosol protein, and nuclear protein were separately extracted from lung tissues $24 \mathrm{~h}$ after the last aerosol challenge. The expression level of NF- $\mathrm{kB}$ p65 and IкBa were analyzed by Western Blot analysis. Our data showed that IkBa were degraded in OVA-challenged mice (Fig. 9A and 9B). OVA stimulation induced the phosphorylation of both p65 and $\mathrm{I} \mathrm{BBa}$ (Fig. 9A, 9C and 9F), and induced the translocation of p65 into the nucleus (Fig. 9E, 9G and 9H). Deguelin $(4 \mathrm{mg} / \mathrm{ml})$ attenuated the phosphorylation of IкBa and p65, and decreased the nucleus level of $\mathrm{p} 65$, with the increase of the cytoplasmic level of p65 (Fig. 9A, 9C and 9E-H). The total NF-kB p65 subunit showed similar patterns as p-p65 (Fig. 9A, 9D and 9F).

To further assess effects of deguelin on TNF- $\alpha$ induced NF- $\mathrm{KB}$ activation in vitro, we examined total NF- $\mathrm{kB}$ p65, IкBa, the phosphorylation of p65, and IKBa in BEAS-2B cells, using Western Blot analysis. As a result, TNF-a induced a rapid phosphorylation of p65 and IкBa, leading to a degradation of IкBa (Fig. 10). However, deguelin markedly inhibited the TNF- $\alpha$ induced phosphorylation of p65 and ІкBa, and suppressed the degradation of ІкBa (Fig. 10A, 10B, $10 \mathrm{C}$ and 10D). Furthermore, we found that TNF-a induced the translocation of p65 into the nucleus in BEAS-2B cells, which was inhibited by deguelin (Fig. $10 \mathrm{~A}$ and 10F). These results confirmed that deguelin inhibited TNF-a induced translocation of p65 to the nucleus by suppressing phosphorylation of p65 and IKBa in cytoplasm, leading to reduced NF-KB activity in epithelial cells. 
A
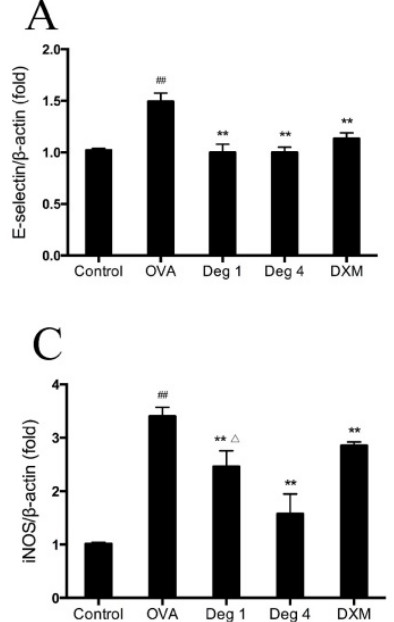

B

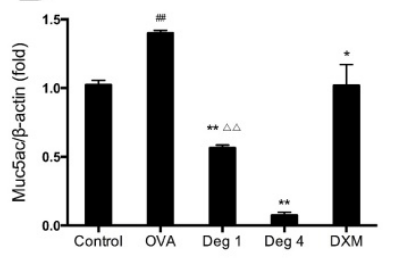

D

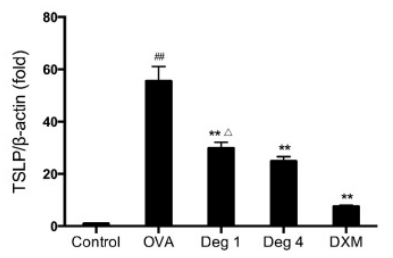

E
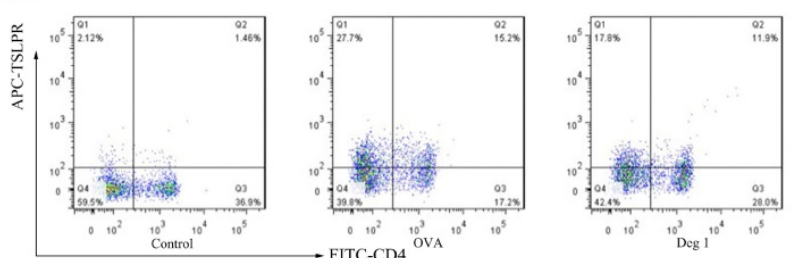

$\mathrm{F}$

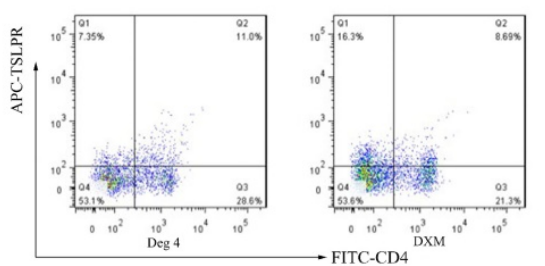

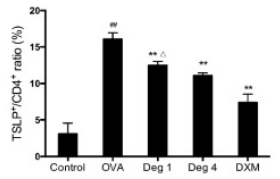

Figure 7. Deguelin reduced OVA-induced inflammatory gene expression in lung tissues. (A, B, C, D) Lung tissues were collected $24 \mathrm{~h}$ after the last OVA challenge. Total mRNA was extracted using TRIzol reagent. The gene expression of E-selecitn, Muc5ac, iNOS and TSLP were detected by real-time RT-PCR. $\beta$-actin was used as an internal control. (E) Lung tissues were collected $24 \mathrm{~h}$ after the last OVA challenge. Single-cell suspensions prepared from lung tissues were double-stained with FITC-conjugated anti-CD4 and APC-conjugated anti-TSLP Receptor, and were analyzed by flow cytometry and software Flowjo 7.6. (F) Ratios of TSLP+/CD4+ $T$ cells were presented. Values are shown as mean $\pm \operatorname{SEM}(\mathrm{n}=6$ for each group). Deg $1=$ Deguelin $1 \mathrm{mg} / \mathrm{kg}$; Deg $4=$ Deguelin $4 \mathrm{mg} / \mathrm{kg}$; DXM = dexamethasone. $\# P<0.05$, $\# P<0.01$ vs. Control group; ${ }^{*} P<0.05,{ }^{* *} P<0.01$ vs. OVA-challenged group; $\triangle P<0.05, \Delta \Delta P<0.01$ vs. Deguelin $(4 \mathrm{mg} / \mathrm{kg})$ group.

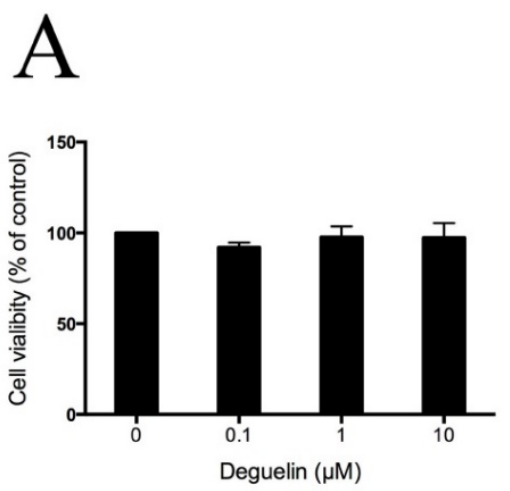

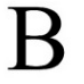
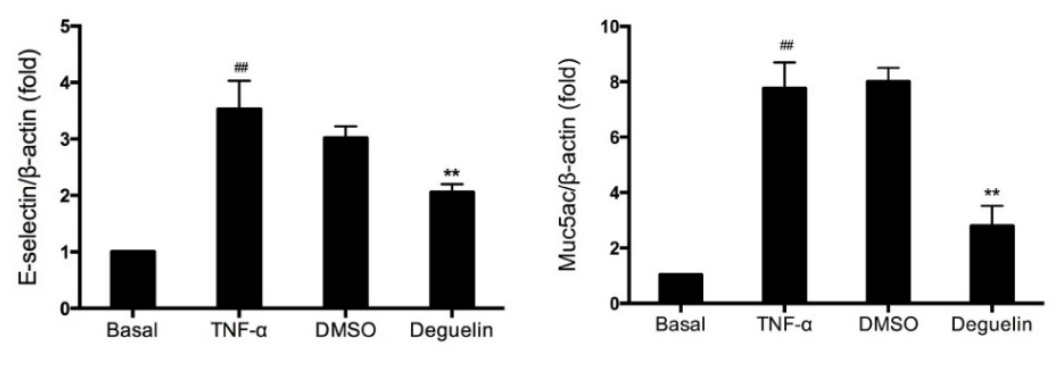

$\mathrm{D}$

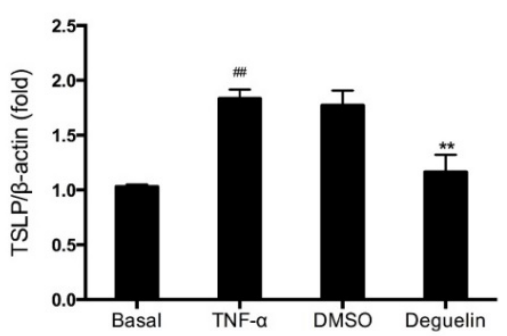

$\mathrm{E}$

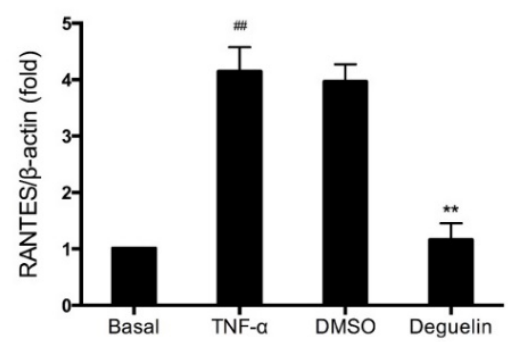

Figure 8. Effects of deguelin on TNF- $\alpha$ induced inflammatory gene expression in BEAS-2B cells. (A) BEAS-2B cells were incubated in the presence or absence of different concentrations of deguelin for $24 \mathrm{~h}$. Cell viability was measured with CCK-8 assay. (B, C, D, E) Cells were pretreated with $10 \mu \mathrm{M}$ deguelin for $24 \mathrm{~h}$ and subsequently treated with $10 \mathrm{ng} / \mathrm{ml}$ TNF- $\alpha$ for $30 \mathrm{~min}$. Total mRNA was extracted using Trizol reagent. The effects of deguelin on the mRNA expression of E-selectin, Muc5ac, TSLP, and RANTES were measured by real-time RT-PCR. DMSO was used as a negative control. $\beta$-actin was used as an internal control. Values are shown

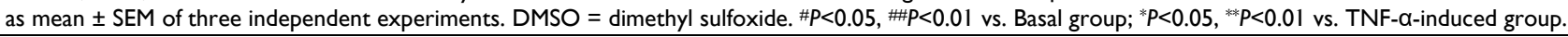



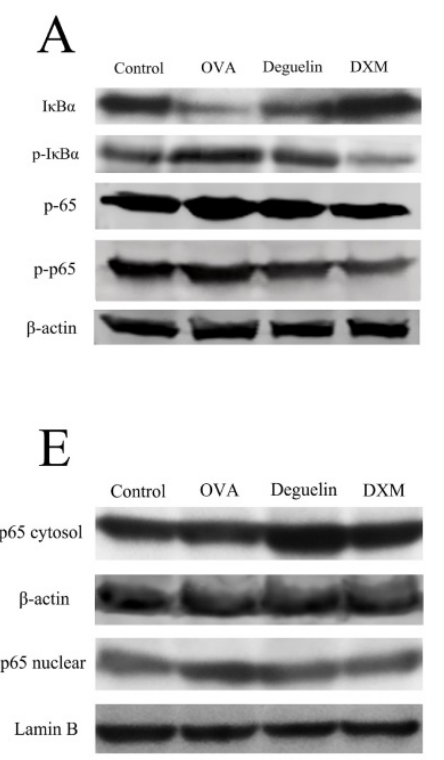

B

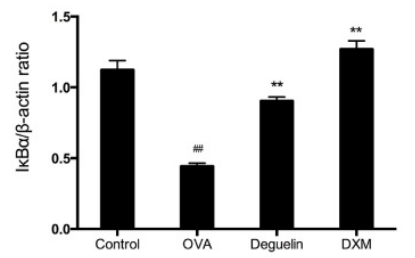

F

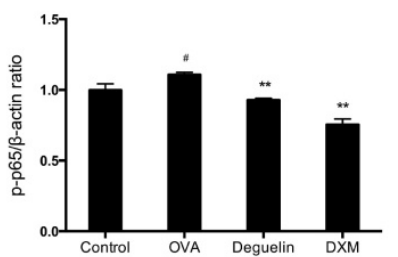

C

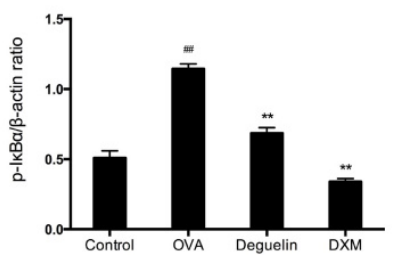

G

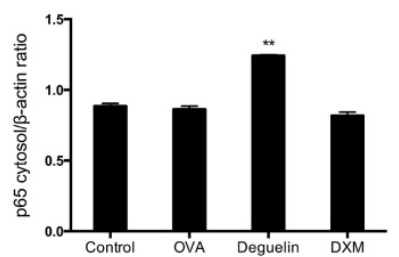

D

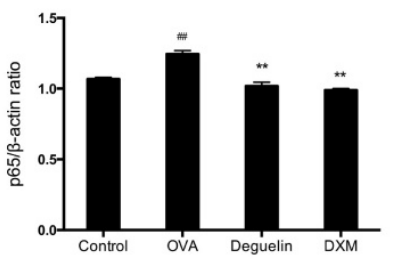

$\mathrm{H}$

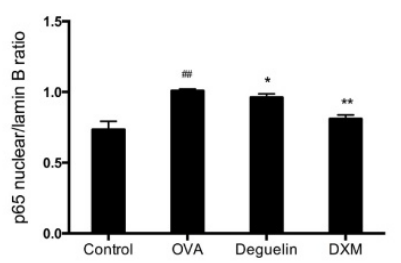

Figure 9. Deguelin suppressed OVA-induced NF-KB activation in lung tissues. Total protein, cytosol protein and nuclear protein were separately extracted from lung tissues $24 \mathrm{~h}$ after the last OVA challenge. (A) Expressions of NF-KB p65, phospho-p65, IKBa, and phosph-IkBa were analyzed by western blotting analysis. $\beta$-actin was used as an internal control. (E) Expressions of cytosol p65 and nuclear p65 were analyzed by western blotting. $\beta$-actin and Lamin $B$ were used as internal controls. (B, $\mathrm{C}, \mathrm{D}, \mathrm{F}, \mathrm{G}, \mathrm{H}$ ) Grey values of the indicated proteins were measured by Quantity One software. Values are shown as mean $\pm \mathrm{SEM}(\mathrm{n}=6$ for each group). $\mathrm{DXM}=$ dexamethasone. $\# P<0.05, \# P<0.01$ vs. Control group; ${ }^{*} P<0.05,{ }^{* *} P<0.01$ vs. OVA-challenged group.

A

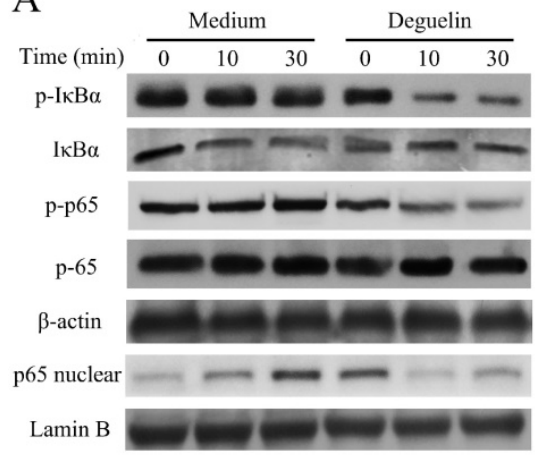

B $\quad$ C

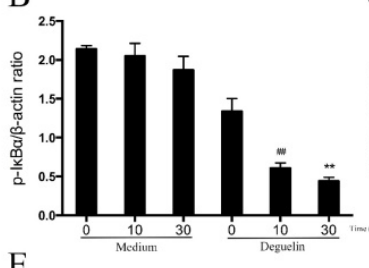

E

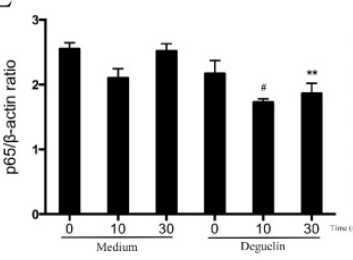

C

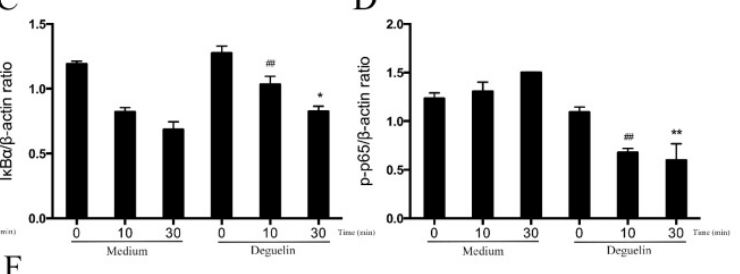

$\mathrm{F}$

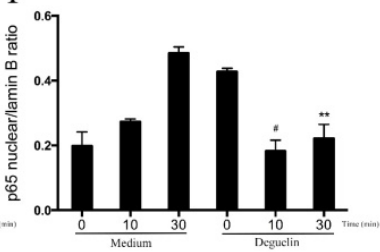

Figure 10. Effects of deguelin on TNF- $\alpha$ induced NF-KB activation in BEAS-2B cells. BEAS-2B cells were pretreated with $10 \mu M$ deguelin for $24 \mathrm{~h}$ and then exposed to $10 \mathrm{ng} / \mathrm{ml}$ TNF- $\alpha$ for the indicated times. (A) Expressions of NF-KB p65, phospho-p65, IKBa, phospho-IKBa and nuclear p65 were analyzed by Western Blotting analysis. $\beta$-actin and Lamin B were used as internal controls. (B, C, D, E, F) Grey values of the indicated proteins were measured by $Q$ uantity One software. Values are shown as mean \pm SEM of three independent experiments. ${ }^{*} P<0.05, \ldots+1<0.01$ vs. Medium plus TNF- $\alpha-10$ min group; ${ }^{*} P<0.05$, ${ }^{* *} P<0.01$ vs. Medium plus TNF- $\alpha-30$ min group.

\section{Discussion}

In this study, we have shown that deguelin effectively reduced OVA-induced infiltration of inflammatory cells, mucus production, AHR, and expression of immunoglobulin and Th2 cytokines in asthmatic mice. In addition, we found that deguelin reduced inflammatory gene expressions both in vivo and in vitro, which were closely associated with activation of the NF-kB signaling pathway. Thus, we further explored the underlying mechanisms of deguelin in BEAS-2B cells. We found that deguelin inhibited the phosphorylation of IKBa and p65 in
BEAS-2B cells, leading to suppression of the NF-kB-associated inflammatory cascade. To our knowledge, it was the first time to investigate the anti-inflammatory effects of deguelin in a mouse model of bronchial asthma and deguelin may be a potent therapeutic agent for asthma.

The eosinophil is a fully delineated granulocyte that disseminates throughout the bloodstream to end organs after complete maturation in the bone marrow. While the presence of eosinophils is not uncommon even in healthy individuals, these granulocytes play a central role in the pathogenesis of allergic inflammation, particularly in the respiratory system, 
such as asthma [19]. Results of our study showed that after sensitization and challenge with OVA, the number of total inflammatory cells, eosinophils, macrophages and lymphocytes increased significantly in BALF. Deguelin treatment noticeably prevented inflammatory cell infiltration into the airways as showed by a significant decrease in total cell counts, eosinophils and macrophages in a dose-dependent manner. The histological examination of H\&E stained lung tissues revealed infiltration of inflammatory cells, such as lymphocytes and eosinophils after the OVA-challenge. OVA-challenged mice also showed a strong $\mathrm{AB} / \mathrm{PAS}$-positive staining in bronchial epithelial tissue, indicating goblet cell hyperplasia and mucus production. Our date showed deguelin treatment significantly alleviated inflammatory cell infiltration, goblet cell hyperplasia, and mucus production.

Th2 cytokines induce the changes in the airways and lung parenchyma that are associated with asthma includes airway eosinophilia, pulmonary lymphocytosis and mastocytosis, alternative macrophage activation, epithelial cell proliferation with goblet cell hyperplasia, increased mucus secretion, smooth muscle hyperplasia, hypertrophy and hypercontractility, subepithelial fibrosis, IgE secretion, and increased production of chemokines that attract $\mathrm{T}$ cells, eosinophils, neutrophils and mast cells or their precursors to the lungs [20]. IL-4, IL-5, and IL-13 can be produced by various lung resident cells, such as bronchial epithelial cells, tissue mast cells, and alveolar macrophages, as well as infiltrated inflammatory cells, such as lymphocytes and eosinophils. It is well known that alternations in cytokines, with over production of Th2 cytokines (IL-4, IL-5, and IL-13) in concert with reduction of Th1 cytokines (IFN- $\gamma$ ), play central roles in pathogenesis of asthma [4]. Our present results showed increased levels of IL-4, IL-5, and IL-13 in OVA-challenged group in BALF. Deguelin significantly reduced the levels of Th2 cytokines (IL-4, IL-5 and IL-13) in a dose-dependent manner. However, there was no significantly difference in IFN- $\gamma$. Both ELISA and RT-PCR revealed similar results. These results suggested that deguelin induced a shift from a Th2-skewed response to a balanced Th1/Th2 response, inhibiting the asthmatic inflammation.

AHR has been used in epidemiological studies as a useful marker of airway abnormalities in asthma, and it is a predictor of the subsequent course of the disease [21]. It is believed that inflammatory mediators released during the allergic inflammation play a critical role in AHR development [22]. It has been reported that IL-4 and IL-13 play critical roles in the development of AHR[23, 24], and IL-5 can induce
AHR by mobilizing and activating eosinophils, leading to the release of proinflammatory products, which are closely associated with AHR [25]. In our study, we demonstrated that deguelin significantly ameliorated OVA-induced AHR to increasing concentrations of methacholine. These were in accordance with our hypothesis that deguelin reduced Th2 cytokine production. Elevated serum IgE level is a hallmark of the Th2 immune response. IgG1 has been used as a Th2 marker and is correlated with IgE levels [26]. Total IgE and IgG1, but not IgG2a levels predicted murine antigen-specific responses [27]. Deguelin strongly suppressed the serum levels of IgE and IgG1, not IgG2a, indicating that a specific inhibition of the Th2 response by deguelin in murine asthmatic model. Thus, the observed reduction of AHR by deguelin may be associated with reduction of Th2 cytokine production and serum immunoglobulins levels.

TSLP is an epithelial-cell-derived cytokine that is important in initiating allergic inflammation. It plays a key role in allergen-induced airway responses and persistent airway inflammation in patients with allergic asthma [28]. In addition, TSLP controls allergic Th2 inflammatory responses through induction of distinct activation programs in dendritic cells (DCs) [29]. A novel double-blind, placebo-controlled study revealed that treatment with AMG157, a human anti-TSLP monoclonal immunoglobulin, reduced allergen-induced bronchoconstriction and indexes of airway inflammation before and after allergen challenge [28]. We have reason to believe that TSLP plays a key role in allergen-induced airway responses and persistent airway inflammation, especially in allergic asthma. Our date showed that deguelin markedly reduced both the mRNA expression and protein production of TSLP in the lungs of OVA-challenged mice by RT-PCR and flow cytometry analyses. These dates indicated that deguelin alleviate allergen-induced airway inflammation through TSLP signaling mechanisms, which need to be further unraveled.

As we have mentioned before, E-selectin is an important adhesion molecule for pulmonary recruitment of inflammatory cells such as eosinophils, which expressed only on endothelial cells activated by cytokines [30]. Muc5ac, which is essential for mucus hypersecretion, is a major mucin protein secreted from the airway surface epithelium and its expression is markedly upregulated in lung tissue in OVA-induced asthmatic mice [31, 32]. iNOS, a pro-inflammatory enzyme responsible for $\mathrm{NO}$ production in allergic airway inflammation, is involved in the pathogenesis of inflammation and cancer inflammation [33]. RANTES, also known as 
CCL5, is one of the cytokines orchestrating leukocyte transmigration into the airways in combination with adhesion molecules, such as E-selectin [34]. We have demonstrated that deguelin markedly downregulated the mRNA expression of E-selectin, Muc5as, and iNOS in the lungs of OVA-challenged mice. Our date also has shown that the suppression of Muc5as, E-selectin and RANTES mRNA expression in TNF-a-stimulated BEAS-2B cells. Our results are similar to those of other previous published studies. Interestingly, E-selectin contains the $\kappa \mathrm{B}$ site for NF-kB within their promoters. Previous studies reported that inflammatory cytokines, like TNF- $\alpha$, induce Muc5ac gene expression through activation of the NF-kB pathway in the lung epithelial cells [35]. NF-кB increases the expression of the genes encoding pro-inflammatory cytokines and enzymes like iNOS and RANTES [36-38]. In addition, TSLP is also regulated by NF-kB together with some important cytokines [39]. Taken together, we considered the observed reduction of airway inflammation by deguelin be a result of combined inhibitory effects of associated cytokines and adhesion molecules, which was closely related to inhibition of NF-KB activation.

Inflammation is the process of innate immunity in response to physical, physiological and/or oxidative stress and is associated with activation of the canonical NF- $\mathrm{kB}$ signaling pathway, which is conserved in all multicellular animals [40]. Persistent NF-kB activation has been observed in allergic airway inflammation both in human and in animal models [41]. Futhermore, NF-kB induces cytokines that regulate the immune response, as well as adhesion molecules, which lead to recruitment of leukocytes to sites of inflammation [40]. In addition, TNF-a stimulation of airway epithelial cells triggers NF-kB-dependent gene expression $[42,43]$. It has been reported that the suppression of TNF-induced NF-KB activation by deguelin occurred through the inhibition of the activation of IкBa kinase, leading to suppression of ІкBa phosphorylation, ІкBa degradation, p65 phosphorylation, p65 nuclear translocation in tumor cells [15]. To confirm the mechanism of the reduction of OVA-induced inflammation in mice through treatment of deguelin, we assessed the potential effects of deguelin on the activation of NF-kB. Our Western Blot analysis revealed that deguelin suppressed the phosphorylation of p65 and decreased the nucleus level of p65 in lungs in OVA-challenged mice. In addition, our results showed that deguelin inhibited the phosphorylation of p65 and IкBa, suppressed the translocation of p65 into the nucleus, and the degradation of IкBa in TNF-a-stimulated BEAS-2B cells in vitro. We have confirmed that during the progression of inflammation, deguelin potentially inhibited NF- $\mathrm{kB}$ binding activity by preventing the translocation of NF-kB p65 into the nucleus, and enhanced the ability of IKBa to maintain NF-KB in an inactive form in the cytoplasm.

\section{Conclusion}

In summary, our results demonstrated that deguelin effectively reduced OVA-induced inflammatory cell recruitment in BALF, decreased inflammatory cell infiltration and mucus production in lungs, suppressed AHR, and inhibited serum immunoglobulin and Th2 cytokines in asthmatic model. In addition, deguelin suppressed inflammatory gene expressions both in vivo and in vitro. Furthermore, deguelin prevented phosphorylation of IKBa and p65 and suppressed translocation of $\mathrm{p} 65$, leading to inactivation of NF- $\mathrm{kB}$ signaling pathways in lung epithelial cells. Our findings suggest deguelin may be a potential therapeutic drug for patients with allergic airway inflammation.

\section{Acknowledgements}

The authors thank Professor Qiangmin Xie (Zhejiang Respiratory Drugs Research Laboratory of SFDA of China, School of Medicine, Zhejiang University) for providing the Whole Body Plethysmograph System. This study was supported by Zhejiang Provincial Natural Science Foundation (No: LY14H010002) and Project of Health and Family Planning Commission of Zhejiang Province, China (No: 2014KYB8098).

\section{Competing Interests}

The authors have declared that no competing interest exists.

\section{References}

1. Beasley R, Semprini A, Mitchell EA. Risk factors for asthma: is prevention possible? Lancet. 2015; 386: 1075-85.

2. Carr TF, Kraft M. Update in Asthma 2014. American journal of respiratory and critical care medicine. 2015; 192: 157-63.

3. Licona-Limon P, Kim LK, Palm NW, Flavell RA. TH2, allergy and group 2 innate lymphoid cells. Nature immunology. 2013; 14: 536-42.

4. Lama M, Chatterjee M, Nayak CR, Chaudhuri TK. Increased interleukin-4 and decreased interferon-gamma levels in serum of children with asthma. Cytokine. 2011; 55: 335-8.

5. Krug N, Hohlfeld JM, Kirsten AM, Kornmann O, Beeh KM, Kappeler D, et al. Allergen-induced asthmatic responses modified by a GATA3-specific DNAzyme. The New England journal of medicine. 2015; 372: 1987-95.

6. Wu W, Hai $Y$, Chen L, Liu RJ, Han YX, Li WH, et al. Deguelin-induced blockade of PI3K/protein kinase B/MAP kinase signaling in zebrafish and breast cancer cell lines is mediated by down-regulation of fibroblast growth factor receptor 4 activity. Pharmacology research \& perspectives. 2016; 4: e00212.

7. Hu J, Ye H, Fu A, Chen X, Wang Y, Chen X, et al. Deguelin--an inhibitor to tumor lymphangiogenesis and lymphatic metastasis by downregulation of vascular endothelial cell growth factor-D in lung tumor model. International journal of cancer Journal international du cancer. 2010; 127: 2455-66.

8. Yan B, Zhao D, Yao Y, Bao Z, Lu G, Zhou J. Deguelin Induces the Apoptosis of Lung Squamous Cell Carcinoma Cells through Regulating the Expression of Galectin-1. International journal of biological sciences. 2016; 12: 850-60. 
9. Jin $\mathrm{Q}$, Feng L, Behrens C, Bekele BN, Wistuba II, Hong WK, et al. Implication of AMP-activated protein kinase and Akt-regulated survivin in lung cancer chemopreventive activities of deguelin. Cancer research. 2007; 67: 11630-9.

10. Liu YP, Lee JJ, Lai TC, Lee CH, Hsiao YW, Chen PS, et al. Suppressive function of low-dose deguelin on the invasion of oral cancer cells by downregulating tumor necrosis factor alpha-induced nuclear factor-kappa B signaling. Head \& neck. 2015.

11. Dell'Eva R, Ambrosini C, Minghelli S, Noonan DM, Albini A, Ferrari N. The Akt inhibitor deguelin, is an angiopreventive agent also acting on the NF-kappaB pathway. Carcinogenesis. 2007; 28: 404-13.

12. Ye H, Xie C, Wu W, Xiang M, Liu Z, Li Y, et al. Millettia pachycarpa exhibits anti-inflammatory activity through the suppression of LPS-induced NO/iNOS expression. The American journal of Chinese medicine. 2014; 42: 949-65.

13. Bao Z, Guan S, Cheng C, Wu S, Wong SH, Kemeny DM, et al. A novel antiinflammatory role for andrographolide in asthma via inhibition of the nuclear factor-kappaB pathway. American journal of respiratory and critical care medicine. 2009; 179: 657-65.

14. Yao Y, Lu S, Li H, Lu G, Zhou J. Low doses of exogenous interferon-gamma attenuated airway inflammation through enhancing Fas/FasL-induced CD4+ $\mathrm{T}$ cell apoptosis in a mouse asthma model. Journal of interferon \& cytokine research : the official journal of the International Society for Interferon and Cytokine Research. 2012; 32: 534-41.

15. Nair AS, Shishodia S, Ahn KS, Kunnumakkara AB, Sethi G, Aggarwal BB. Deguelin, an Akt inhibitor, suppresses IkappaBalpha kinase activation leading to suppression of NF-kappaB-regulated gene expression, potentiation of apoptosis, and inhibition of cellular invasion. Journal of immunology. 2006; 177: 5612-22.

16. Froidure A, Shen C, Gras D, Van Snick J, Chanez P, Pilette C. Myeloid dendritic cells are primed in allergic asthma for thymic stromal lymphopoietin-mediated induction of Th2 and Th9 responses. Allergy. 2014; 69: 1068-76.

17. Gerondakis S, Fulford TS, Messina NL, Grumont RJ. NF-kappaB control of T cell development. Nature immunology. 2014; 15: 15-25.

18. Hayden MS, Ghosh S. Regulation of NF-kappaB by TNF family cytokines. Seminars in immunology. 2014; 26: 253-66.

19. Eng SS, DeFelice ML. The Role and Immunobiology of Eosinophils in the Respiratory System: a Comprehensive Review. Clinical reviews in allergy \& immunology. 2016; 50: 140-58.

20. Finkelman FD, Hogan SP, Hershey GK, Rothenberg ME, Wills-Karp M. Importance of cytokines in murine allergic airway disease and human asthma. Journal of immunology. 2010; 184: 1663-74.

21. Liang Z, Nie H, Xu Y, Peng J, Zeng Y, Wei Y, et al. Therapeutic effects of rosmarinic acid on airway responses in a murine model of asthma. International immunopharmacology. 2016; 41: 90-7.

22. Cockcroft DW, Davis BE. Mechanisms of airway hyperresponsiveness. The Journal of allergy and clinical immunology. 2006; 118: 551-9; quiz 60-1.

23. Leigh R, Ellis R, Wattie JN, Hirota JA, Matthaei KI, Foster PS, et al. Type 2 cytokines in the pathogenesis of sustained airway dysfunction and airway remodeling in mice. American journal of respiratory and critical care medicine. 2004; 169: 860-7.

24. Vargaftig BB, Singer M. Leukotrienes mediate murine bronchopulmonary hyperreactivity, inflammation, and part of mucosal metaplasia and tissue injury induced by recombinant murine interleukin-13. American journal of respiratory cell and molecular biology. 2003; 28: 410-9.

25. Takatsu K, Nakajima H. IL-5 and eosinophilia. Current opinion in immunology. 2008; 20: 288-94.

26. Wee JH, Zhang YL, Rhee CS, Kim DY. Inhibition of Allergic Response by Intranasal Selective NF-kappaB Decoy Oligodeoxynucleotides in a Murine Model of Allergic Rhinitis. Allergy, asthma \& immunology research. 2017; 9; 61-9.

27. Lewkowich IP, Rempel JD, HayGlass KT. Antigen-specific versus total immunoglobulin synthesis: total IgE and IgG1, but not IgG2a levels predict murine antigen-specific responses. International archives of allergy and immunology. 2004; 133: 145-53.

28. Gauvreau GM, O'Byrne PM, Boulet LP, Wang Y, Cockcroft D, Bigler J, et al. Effects of an anti-TSLP antibody on allergen-induced asthmatic responses. The New England journal of medicine. 2014; 370: 2102-10.

29. Melum GR, Farkas L, Scheel C, Van Dieren B, Gran E, Liu YJ, et al. A thymic stromal lymphopoietin-responsive dendritic cell subset mediates allergic responses in the upper airway mucosa. The Journal of allergy and clinical immunology. 2014; 134: 613-21 e7.

30. Schnoor M. Endothelial actin-binding proteins and actin dynamics in leukocyte transendothelial migration. Journal of immunology. 2015; 194: 3535-41.

31. Tan YF, Zhang W, Yang L, Jiang SP. The effect of formoterol on airway goblet cell hyperplasia and protein Muc5ac expression in asthmatic mice. European review for medical and pharmacological sciences. 2011; 15: 743-50.

32. Kurakula K, Hamers AA, van Loenen P, de Vries CJ. 6-Mercaptopurine reduces cytokine and Muc5ac expression involving inhibition of NFkappaB activation in airway epithelial cells. Respiratory research. 2015; 16: 73.

33. Mauriz JL, Collado PS, Veneroso C, Reiter RJ, Gonzalez-Gallego J. A review of the molecular aspects of melatonin's anti-inflammatory actions: recent insights and new perspectives. Journal of pineal research. 2013; 54: 1-14.

34. Kelly M, Hwang JM, Kubes P. Modulating leukocyte recruitment in inflammation. The Journal of allergy and clinical immunology. 2007; 120: 3-10.
35. Fujisawa T, Velichko S, Thai P, Hung LY, Huang F, Wu R. Regulation of airway MUC5AC expression by IL-1beta and IL-17A; the NF-kappaB paradigm. Journal of immunology. 2009; 183: 6236-43.

36. Choi YH, Na BH, Choi YS, Saifur Rahman M, Kim MR, Jee JP, et al. Anti-inflammatory function of 4-tert-butylphenyl salicylate through down-regulation of the NF-kappa B pathway. Archives of pharmacal research. 2016.

37. Chaturvedi MM, Sung B, Yadav VR, Kannappan R, Aggarwal BB. NF-kappaB addiction and its role in cancer: 'one size does not fit all'. Oncogene. 2011; 30: 1615-30.

38. Marques RE, Guabiraba R, Russo RC, Teixeira MM. Targeting CCL5 in inflammation. Expert opinion on therapeutic targets. 2013; 17: 1439-60.

39. Causton B, Ramadas RA, Cho JL, Jones K, Pardo-Saganta A, Rajagopal J, et al. CARMA3 Is Critical for the Initiation of Allergic Airway Inflammation. Journal of immunology. 2015; 195: 683-94.

40. Hoesel B, Schmid JA. The complexity of NF-kappaB signaling in inflammation and cancer. Molecular cancer. 2013; 12: 86

41. Pantano C, Ather JL, Alcorn JF, Poynter ME, Brown AL, Guala AS, et al. Nuclear factor-kappaB activation in airway epithelium induces inflammation and hyperresponsiveness. American journal of respiratory and critical care medicine. 2008; 177: 959-69.

42. Newton R, Holden NS, Catley MC, Oyelusi W, Leigh R, Proud D, et al. Repression of inflammatory gene expression in human pulmonary epithelial cells by small-molecule IkappaB kinase inhibitors. The Journal of pharmacology and experimental therapeutics. 2007; 321: 734-42.

43. Xia $Y$, Shen S, Verma IM. NF-kappaB, an active player in human cancers. Cancer Immunol Res. 2014: 2: 823-30. 